J. Clin. Chem. Clin. Biochem.

Vol. 20, 1982, pp. 499-507

\title{
The Suitability of the lliac Crest Biopsy in the Element Analysis of Bone and Marrow
}

\author{
By D. Gawlik, D. Behne, P. Brätter, W. Gatschke, H. Gessner
}

Hahn-Meitner-Institut für Kernforschung Berlin GmbH and

D. Kraft

Klinikum Steglitz der Freien Universität Berlin

(Received September 29, 1981/March 29, 1982)

Summary: Bone samples from the iliac crest were taken from 20 subjects and the content of some trace elements (iron, zinc, selenium, cobalt, strontium, aluminium, scandium, rubidium and fluorine) and of the matrix elements calcium, phosphorus and sodium was determined. The samples were taken in accordance with Burkhardt's method, which is often used in hospital for bone biopsies. The sources of errors occurring during the analysis of trace elements using this clinical procedure and the contamination of the samples by blood and the surrounding tissue are discussed. In-vivo activation analysis is also discussed as an alternative method of element analysis of the skeleton.

\section{Die Eignung der Beckenkammbiopsie zur Elementanalyse in Knochen und Mark}

Zusammenfassung: Es wurden die Gehalte einiger Spurenelemente (Eisen, Zink, Selen, Cobalt, Strontium, Aluminium, Scandium, Rubidium und Fluor) und der Matrix-Elemente Calcium, Phosphor und Natrium in Knochenproben aus dem Beckenkamm von 20 Personen bestimmt. Die Proben waren nach einem in der Klinik für Knochenbiopsien häufig verwendeten Verfahren nach Burkhardt genommen worden. Die Fehlermöglichkeiten bei der Analyse der Spurenelemente unter Verwendung dieses klinischen Verfahrens und die Kontamination der Proben durch Blut und angrenzende Gewebe werden diskutiert. Es wird als alternative Methode zur Elementbestimmung im Skelett die in-vivo-Aktivierungsanalyse diskutiert.

\section{Introduction}

Reference was recently made to the significance of the storage of elements in bone tissue and their mobilisation from the skeleton $(1,2)$. Three aspects were mentioned:

1) Homeostatic functions of bone tissue in the metabolism of the trace elements.

2) The bone as an internal source of trace elements in the course of pathological (e.g. ricketts, dialysis) and physiological (old age, pregnancy) changes in the bone mass or composition.

3) The possible role of trace elements in the synthesis and calcification of bone tissue.

However, no standard method for the analysis of trace elements in bone has yet been developed as is the case with the analysis of blood components or other tissues. We became aware of this need whilst investigating the influence of long term dialysis on trace element metabolism.
A standard method for trace element analysis must consider the homogeneity of the samples, contamination by e.g. tools or chemicals and, especially with biological samples, contamination by adjacent tissue or by blood. Behne (3) recently summarized the possible sources of error.

In this study we investigated the applicability of the bone biopsy method according to Burkhardt (4-6), commonly used in hospitals, for the trace element analysis of bone.

The bone biopsy taken from the iliac crest to determine a number of histological parameters connected with various diseases (osteoporosis, renal osteopathy) is an obvious choice for the source of material for the additional element analysis. The mass of the biopsy obtained using Burkhardt's method is sufficient for trace element analysis even after half has been taken for histological and cytological investigations. When the cortical substance which is thin in this area has been removed, the 
Tab. 1a. Contents of some matrix elements in bone measured by neutron activation analysis and other analytical methods.

\begin{tabular}{|c|c|c|c|c|c|c|}
\hline & Bone & Tissue*) & $\begin{array}{l}\text { Reference } \\
\text { mass**) }\end{array}$ & $\begin{array}{l}\text { Matrix elements } \\
\mathrm{Ca}\end{array}$ & $\begin{array}{l}\text { (fraction } \times 100) \\
\mathrm{P}\end{array}$ & $\mathbf{N a}$ \\
\hline \multicolumn{7}{|l|}{ Neutron activation analysis } \\
\hline $\begin{array}{l}\text { Batra \& Bewley (9) } \\
\text { Goode (11) } \\
\text { Liebscher \& Smith (12) } \\
\text { Mc Kown et al. (13) } \\
\text { Söremark \& Bergmann (14) } \\
\text { This work }\end{array}$ & $\begin{array}{l}? \\
? \\
? \\
\text { Skull } \\
\text { Mandib. Ramus } \\
\text { lliac crest }\end{array}$ & $\begin{array}{l}? \\
\mathrm{C} / \mathrm{Sp} \\
? \\
\mathrm{C} / \mathrm{Sp} \\
\mathrm{C} \\
\mathrm{Sp}\end{array}$ & $\begin{array}{l}\text { D } \\
\text { A } \\
\text { D } \\
\text { D } \\
\text { D } \\
\text { D, Def }\end{array}$ & $\begin{array}{l}23.8 \\
31 \\
- \\
16.6 \\
25.0 \pm 2.4 \\
21.3 \pm 1.1\end{array}$ & $\begin{array}{l}10.3 \\
- \\
- \\
- \\
- \\
9.8 \pm 0.6(21)\end{array}$ & $\begin{array}{l}\overline{1.01} \\
\overline{0} \\
1.69 \\
0.41 \pm 0.98 \\
0.09 .09\end{array}$ \\
\hline Other analytical methods ( 8 ) & & & $\begin{array}{l}\text { F } \\
\text { D, Def } \\
\text { A }\end{array}$ & $\begin{array}{l}10.8-14.8 \\
17-27.4 \\
35.6-39\end{array}$ & $\begin{array}{l}5 \\
17.4 \\
15.5\end{array}$ & $\begin{array}{l}- \\
-\end{array}$ \\
\hline
\end{tabular}

*) C $=$ Compacta $\mathrm{Sp}=$ Spongiosa $\left.{ }^{* *}\right) \mathrm{F}=$ Fresh $\mathrm{D}=$ Dry Def $=$ Defatted $\mathrm{A}=$ Ashed

sample consists solely of spongy tissue. This tissue, because of the bone remodelling in trabecular bone is more active than in cortical bone, has the advantage of reflecting more rapidly any changes in the composition of bone due to external parameters like medication.

A separation of the cortical from the spongy part is necessary because the trace element content of spongy bone is generally higher than in the compacta. (With fluorine the ratio is 3:1 (20)). A combined analysis of both parts would thus reflect the mass ratio spongiosa/ compacta.

Additionally, the element content of bone marrow is of interest, because this tissue represents an important source of contamination for the adjacent bone.

We could find no information about the trace element content of bone marrow in the literature.
The elements investigated were limited by the analytical method used, namely instrumental neutron activation analysis. In addition to the trace elements iron, zinc, selenium, cobalt, strontium, aluminium, scandium, rubidium and fluorine, the contents of the matrix elements, calcium, phosphorus and sodium were determined in bone.

With neutron activation analysis, which is normally too complicated and time-consuming for clinical analysis, no preparation of the bone sample whatsoever (e.g. dissolving or decomposition) is necessary. Since a number of systematic errors in sampling can be excluded when neutron activation analysis is used it has frequently been applied as a reference method.

This analytical method would therefore seem to be suitable for the problem under investigation.

Studies on trace elements in bone have been carried out in the past. Table 1 contains a list of all the studies

Tab. 1b. Contents of some trace elements in bone measured by neutron activation analysis and other analytical methods.

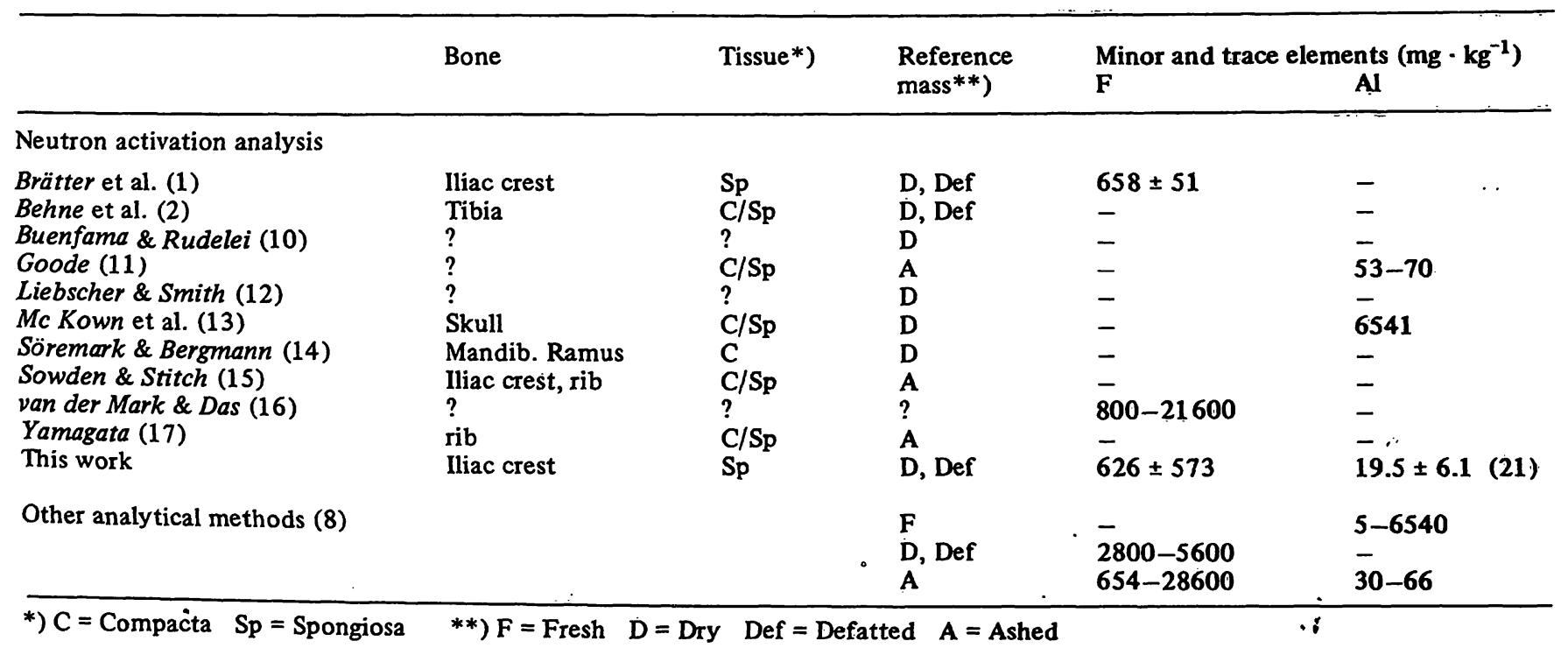


Tab. 2. Composition of the biopsy tools by Burkhardt (Manufacturer Straumann, Switzerland). Values in fractions $X 100$.

\begin{tabular}{|c|c|c|c|c|c|c|c|c|c|c|}
\hline & $\mathrm{Fe}$ & C & $\mathbf{S i}$ & Mn & $\mathbf{P}$ & $\mathbf{S}$ & $\mathrm{Cr}$ & Mo & $\mathbf{V}$ & $\mathrm{Ni}$ \\
\hline Hollow milling cutter & 79.73 & 0.92 & 0.38 & 0.54 & 0.023 & 0.014 & 17.28 & 1.02 & 0.09 & - \\
\hline $\begin{array}{l}\text { Pair of tongs for extraction } \\
\text { of samples }\end{array}$ & 69.68 & 0.12 & 1.0 & 2.0 & - & 0.2 & 18.0 & - & - & 9.0 \\
\hline
\end{tabular}

known to us on the determination of trace elements in bone tissue using neutron activation analysis (including those investigated in this study). It is accompanied by a survey of the range of values obtained with other analyti$\mathrm{cal}$ methods. The literature data from 1.c. (8) were evaluated for this purpose. The bone under investigation, the fraction of compact or spongy tissue and the reference mass were included in the table, as far as they were mentioned in the studies. In view of the fact that the water content varies with bone tissue there would seem to be little point in relating the element masses to the wet weight. In an approximate comparison of the contents related to the dry, fat-free and the ashed bone one can assume a mean ashing loss of $40 \%$.

The wide range of values can certainly not be explained solely by errors in method in the actual analysis, but is also due to the fact that the samples were taken from different parts of the bone (ratio spongiosa/compacta) and to different methods of preparation (e.g. unsatisfactory removal of marrow). This shows how important it is, for the purpose of comparison, to adhere to one method of preparation and to one specific sampling area, which must be defined as clearly as possible.

\section{Materials and Methods}

Post mortem samples were taken approximately 1 day after death from 20 persons (11 male, 9 female) in Klinikum Steglitz, Universität Berlin. All had been suffering from diseases which were assumed to have no effect on the bone. The average age was $71(50-88)$ years. (We are indebted to Professor Groß of the Dep. of Pathology, Klinikum Steglitz, Freie Universität Berlin, for providing us with the bone samples.) Four samples each were taken from the left and the right iliac crest at intervals of $20 \mathrm{~mm}$. The outermost sample had a distance of $20 \mathrm{~mm}$ from the spina iliaca anterior superior. Some of the instruments developed by Burkhardt for myelotomy were used.

The samples, of length $20-25 \mathrm{~mm}$, were taken with a hollow milling cutter with an internal diameter of $4 \mathrm{~mm}$ (about $300 \mathrm{~min}^{-1}$ ) and extraction forceps. The composition of the hollow milling cutter and the forceps material, as given by the manufacturers can be found in table 2 . Immediately after the samples were taken they were fixed as usual in Carnoy's solution for 4 hours. (0.75 1 ethanol, 0.131 chloroform, 0.131 glacial acetic acid) and were then stored in polyethylene vials filled with $700 \mathrm{ml} / 1$ ethanol. As in the case of the biopsies that we investigated, the cylindrical sample was cut in half down the middle. The blade of the saw used was made of bronze and set with diamonds. The samples were then extracted with ether in a Soxhlet apparatus for six hours and subsequently dried at $60^{\circ} \mathrm{C}$ for 24 hours. The part of the marrow which was not soluble in ether could easily be removed under the microscope using a fine brush. This part was collected from 3 persons and analysed in the same way.

The samples were first sealed in polyethylene foil and irradiated in the reactor BER II with the help of a fast pneumatic transfer system at a neutron flux of $2 \times 10^{13} \mathrm{~cm}^{-2} \mathrm{~s}^{-1}$ for 20 seconds. This treatment served for the analysis of calcium, phosphorus, aluminium, fluorine and sodium, using element standards. Details of the measurement of F, Ca and $\mathrm{Na}$ are published in l.c. (20) and of phosphorus and aluminium in 1.c. (21).

After a decay time of only a few days the samples were then sealed in highly pure silica ampoules, activated in the reactor FR 2 in Karlsruhe at a thermal neutron flux density of $5 \cdot 10^{13} \mathrm{~cm}^{-2} \mathrm{~s}^{-1}$ for 10 days and after a decay period of approximately 3 months the element contents were assessed according to the relative method using the standards Bovine Liver (NBS 1577), Orchard Leaves (NBS 1571) and Bowens Kale (measuring time 2 hours). The samples remained in the closed silica ampoules while the gamma spectra were being measured.

\begin{tabular}{|c|c|c|c|c|c|c|}
\hline \multicolumn{7}{|c|}{ Minor and trace elements $\left(\mathrm{mg} \cdot \mathrm{kg}^{-1}\right)$} \\
\hline $\begin{array}{l}0.35 \pm 0.1 \\
0.01\end{array}$ & $\begin{array}{l}598 \div 80 \\
8-50\end{array}$ & $\overline{0} .02-0.5$ & $\begin{array}{l}0.08 \pm 0.01 \\
0.001\end{array}$ & $\begin{array}{l}0.47 \pm 0.08 \\
1\end{array}$ & $162 \pm 8$ & $\begin{array}{l}159 \pm 7 \\
70-150\end{array}$ \\
\hline- & - & $1.9 \pm 0.13$ & - & - & - & - \\
\hline- & - & - & - & - & - & - \\
\hline$\overline{46}$ & - & - & - & - & - & $49.9-129$ \\
\hline $\begin{array}{l}4.6 \\
-\end{array}$ & 2041 & - & 4.6 & - & 967 & - \\
\hline- & - & 5.1 & - & - & $42 \pm 14$ & $117 \pm 58$ \\
\hline - & - & - & - & - & $67-138$ & - \\
\hline- & - & - & - & - & - & - \\
\hline$\overline{0} 016+0027$ & & $7.6 \pm 2.9$ & - & - & $\overline{2}$ & $\overline{151}+22$ \\
\hline $0.046 \pm 0.037$ & $183 \pm 78$ & $<0.04$ & $0.0014 \pm 0.0007$ & $0.13 \pm 0.04$ & $79 \pm 23$ & $151 \pm 22$ \\
\hline- & 115 & - & - & - & 55 & $53-66$ \\
\hline $0.03-43.5$ & $3-40$ & - & - & 8.9 & $75-237$ & $50-170$ \\
\hline- & 707 & - & - & - & $90-160$ & $187-190$ \\
\hline
\end{tabular}




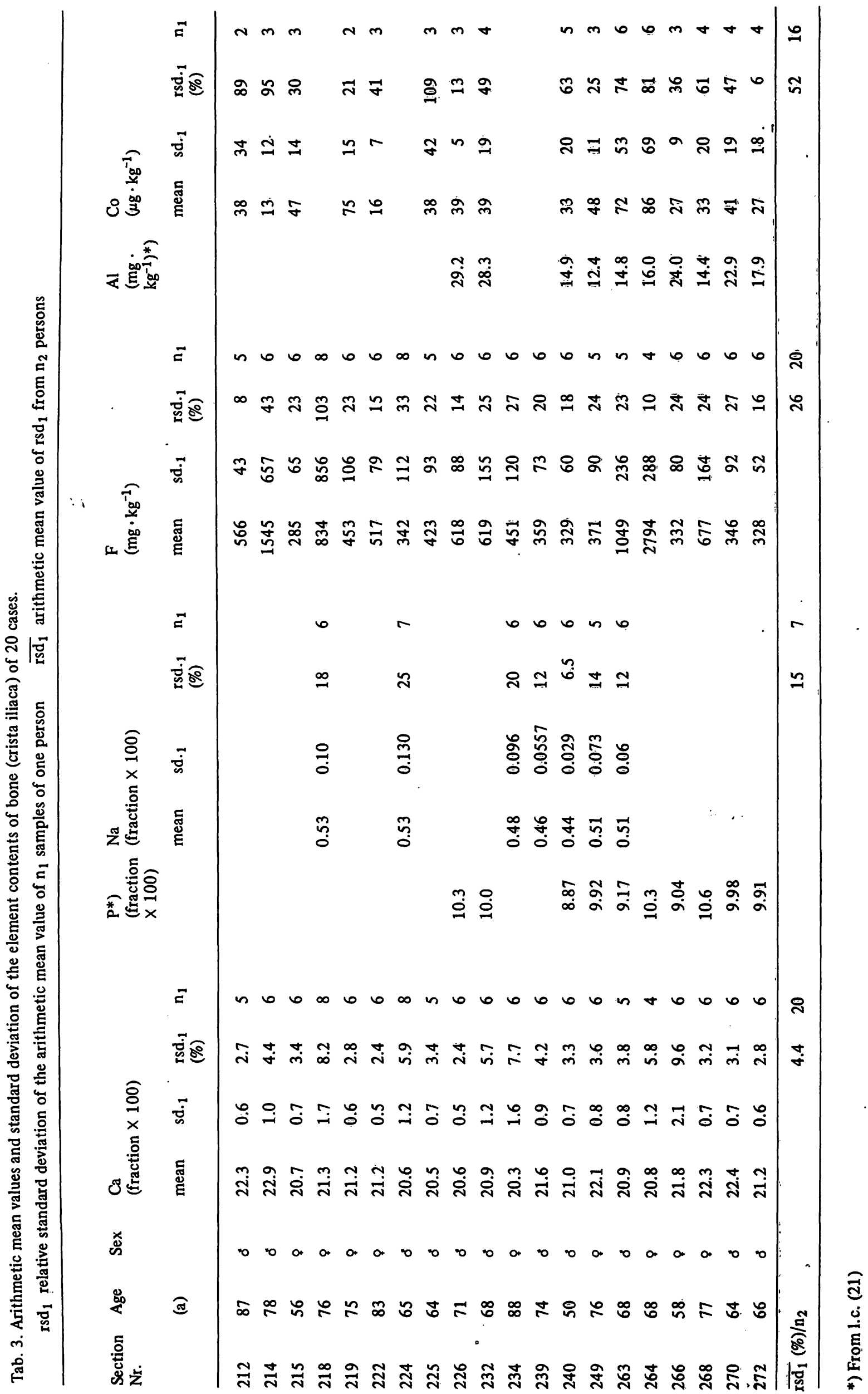




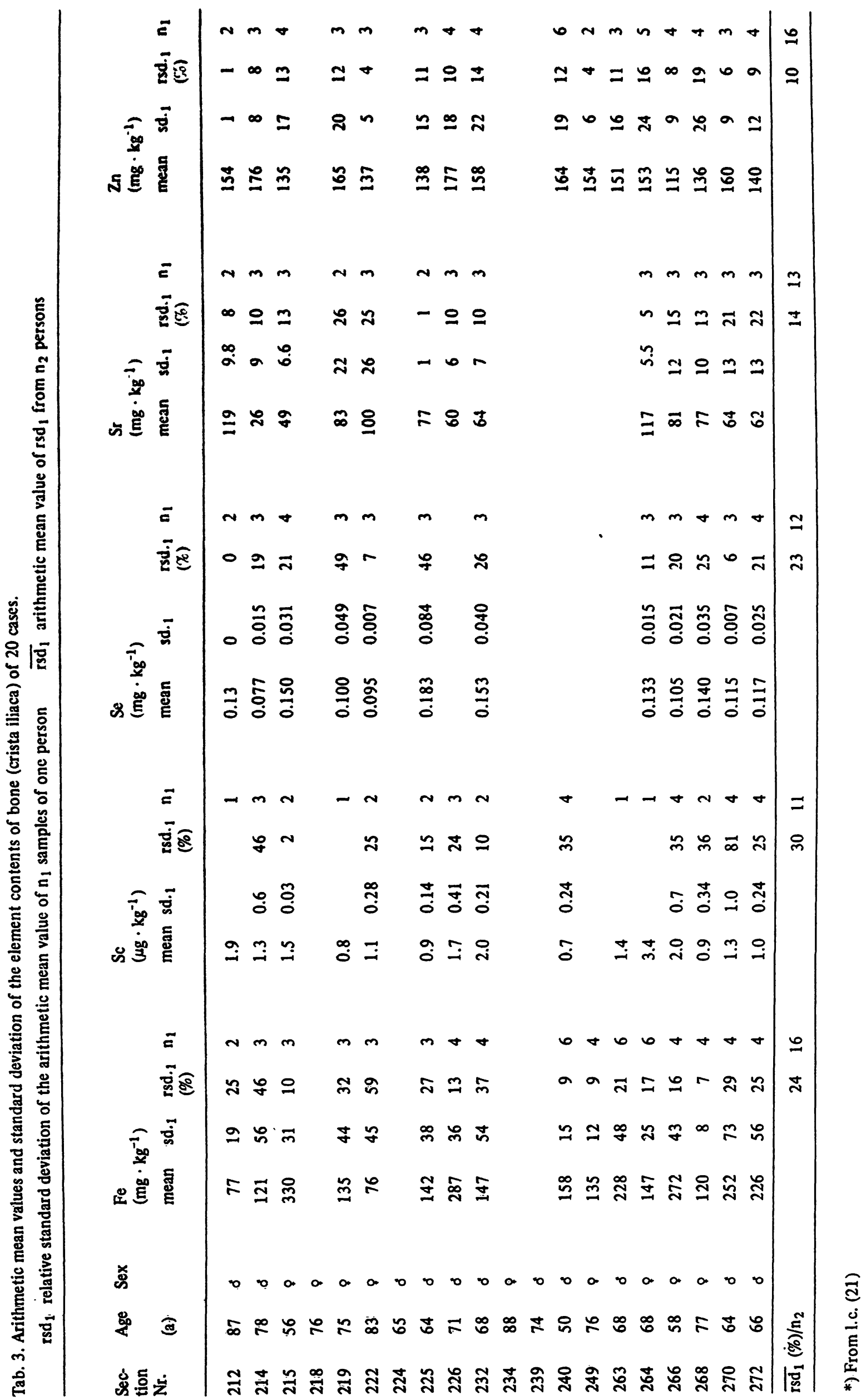




\section{Results}

The arithmetic mean values of the trace element contents in the iliac crest of the 20 persons examined are listed in table 3. This table also includes the standard deviations of the contents of the individual subjects for the discussion of intra-individual distribution.

The phosphorus and aluminium contents have already been published in 1.c. (21). In 2 samples with the section numbers 264 and 266 an attempt was made to determine the rubidium contents via a long-term measurement (measuring time: 3 days). In both samples the content was below the detection limit of $40 \mu \mathrm{g} / \mathrm{kg}$ (See
"Discussion" on the significance of rubidium as a "scout" element for blood in bone).

Table 4 contains the mean values, the standard deviations, the medians and the percentiles for the samples investigated. By way of comparison, in,column 6 , the precision of the neutron activation method is given (standard deviation of the arithmetic mean value of 10 identical samples). For the discussion, column 13 shows the relative content of the element in the mineral, taken from 1.c. (1).

Table 5 shows the results of the measurements of the trace elements in bone marrow.

Tab. 4. Arithmetic mean values and medians of element contents in bone (crista iliaca) (All samples).

\begin{tabular}{|c|c|c|c|c|c|c|c|c|c|c|c|c|}
\hline 1 & 2 & 3 & 4 & 5 & 6 & 7 & 8 & 9 & 10 & 11 & 12 & 13 \\
\hline $\begin{array}{l}\text { Ele- } \\
\text { ment }\end{array}$ & $\begin{array}{l}\text { Number } \\
\text { of } \\
\text { samples }\end{array}$ & $\begin{array}{l}\text { Arithmet. } \\
\text { mean } \\
\text { value } \\
\text { i) }\end{array}$ & $\begin{array}{l}\text { Stand- } \\
\text { ard de- } \\
\text { viation } \\
\text { of mean } \\
\text { value }\end{array}$ & $\begin{array}{l}\text { Rela- } \\
\text { tive } \\
\text { stand- } \\
\text { ard de- } \\
\text { viation } \\
(\%)\end{array}$ & $\begin{array}{l}\text { Preci- } \\
\text { sion*) } \\
\text { of } \\
\text { NAA- } \\
\text { meth- } \\
\text { od } \\
(\%)\end{array}$ & Median & Percenti & $10 \%$ & $90 \%$ & $97.5 \%$ & Unit & $\begin{array}{l}\text { Relative } \\
\text { element } \\
\text { content in } \\
\text { the mineral } \\
\text { (fraction } \\
\times 100 \text { ) } \\
\text { From l.c. (1) }\end{array}$ \\
\hline $\mathrm{Ca}$ & 118 & 21.3 & 1.1 & 5 & 5 & 21.3 & 19.1 & 19.9 & 22.6 & 23.8 & $\begin{array}{l}\text { fraction } \\
\times 100\end{array}$ & $\approx 100$ \\
\hline $\mathbf{P}$ & 10 & 9.8 & 0.6 & 6 & 5 & 9.9 & & 9.04 & 10.3 & & $\begin{array}{l}\text { fraction } \\
\times 100\end{array}$ & \\
\hline $\mathrm{Na}$ & 42 & 0.49 & 0.09 & 17 & 5 & 0.49 & 0.37 & 0.42 & 0.61 & 0.67 & $\begin{array}{l}\text { fraction } \\
\times 100\end{array}$ & $\approx 100$ \\
\hline $\mathrm{F}$ & 118 & 626 & 573 & 92 & 10 & 452 & 232 & 284 & 911 & 2669 & $\mathrm{mg} \cdot \mathrm{kg}^{-1}$ & $\approx 100$ \\
\hline $\mathrm{Al}$ & 10 & 19.5 & 6.1 & 31 & 15 & 16 & & 14.4 & 28.3 & & $\mathrm{mg} \cdot \mathrm{kg}^{-1}$ & \\
\hline Co & 58 & 46 & 37 & 81 & 5 & 36 & 6 & 17 & 74 & 174 & $\mu \mathrm{g} \cdot \mathrm{kg}^{-1}$ & 56 \\
\hline $\mathrm{Fe}$ & 63 & 183 & 78 & 43 & 8 & 165 & 63.8 & 90.7 & 306 & 325 & $\mathrm{mg} \cdot \mathrm{kg}^{-1}$ & 70 \\
\hline $\mathrm{Rb}$ & 2 & n.d. $(<40)$ & & & & & & & & & $\hat{\mu g} \cdot \mathrm{kg}^{-1}$ & \\
\hline Sc & 36 & 1.4 & 0.7 & 51 & 15 & 1.2 & 0.5 & 0.7 & 2.2 & 3.0 & $\mu \mathrm{g} \cdot \mathrm{kg}^{-1}$ & 43 \\
\hline $\mathrm{Se}$ & 29 & 0.13 & 0.04 & 33 & 5 & 0.12 & 0.07 & 0.09 & 0.16 & 0.19 & $\mathrm{mg} \cdot \mathrm{kg}^{-1}$ & 33 \\
\hline $\mathrm{Sr}$ & 36 & 79 & 23 & 29 & 10 & 73 & 46 & 55 & 114 & 126 & $\mathrm{mg} \cdot \mathrm{kg}^{-1}$ & $\approx 100$ \\
\hline $\mathrm{Zn}$ & 56 & 151 & 22 & 15 & 5 & 152 & 111 & 123 & 181 & 190 & $\mathrm{mg} \cdot \mathrm{kg}^{-1}$ & 98 \\
\hline
\end{tabular}

*) Standard deviation of the arithmetic mean value of 10 identical samples. NNA $=$ Neutron activation analysis

Tab. 5. Measured element content (arithmetic mean of 3 cases \pm standard deviation) of bone marrow (defatted, dry) of the iliac crest.

\begin{tabular}{|c|c|c|c|c|c|c|c|c|c|}
\hline $\begin{array}{l}\mathrm{Ca} \\
\text { (fraction } \\
\times 100)\end{array}$ & $\begin{array}{l}P \\
\text { (fraction } \\
\times 100)\end{array}$ & $\begin{array}{l}\mathrm{Na} \\
\text { (fraction } \\
\times 100 \text { ) }\end{array}$ & $\begin{array}{l}F \\
\left(\mathrm{mg} \cdot \mathrm{kg}^{-1}\right)\end{array}$ & $\begin{array}{l}\text { Co } \\
\left(\mu \mathrm{g} \cdot \mathrm{kg}^{-1}\right)\end{array}$ & $\begin{array}{l}\mathrm{Fe} \\
\left(\mathrm{mg} \cdot \mathrm{kg}^{-1}\right)\end{array}$ & $\begin{array}{l}\mathrm{Rb} \\
\left(\mathrm{mg} \cdot \mathrm{kg}^{-1}\right)\end{array}$ & $\begin{array}{l}\mathrm{Se} \\
\left(\mathrm{mg} \cdot \mathrm{kg}^{-1}\right)\end{array}$ & $\begin{array}{l}\mathrm{Sr} \\
\left(\mathrm{mg} \cdot \mathrm{kg}^{-1}\right)\end{array}$ & $\begin{array}{l}\mathrm{Zn} \\
\left(\mathrm{mg}: \mathrm{kg}^{-1}\right)\end{array}$ \\
\hline $8.7 \pm 0.5$ & $5.4 \pm 0.3$ & $0.05 \pm 0.03$ & $243 \pm 106$ & $139 \pm 12$ & $2080 \pm 700$ & n.d. & $0.50 \pm 0.06$ & $180 \pm 30$ & $280 \pm 20$ \\
\hline
\end{tabular}

\section{Discussion}

It was not the aim of this study to investigate the suitability of a particular analytical method for the detection of matrix and trace elements in bone. The accuracy of the method described above has been tested by an intercomparison of the IAEA (23) and proved to be satisfactory.
In table 4, columns 5 and 6, the relative standard deviation of the measurement values and the precision of the neutron activation analysis method in the determination of the elements are listed side by side. The method is, therefore, sufficiently precise to obtain information on other components contributing to the overall error. 
Intra-individual distribution of trace element contents

Mean values and standard deviations were calculated for the individual subjects (tab. 3) after it had been shown that there was no significant pattern in the spatial distribution of the elements across the iliac crest. A measure for intra-individual distribution is the arithmetic mean value $\overline{\text { rsd }}$ (tab. 3 ) of the individual standard deviations rsd. These mean deviations range between $4.4 \%$ (calcium) and $52 \%$ (cobalt).

The range of values within one individual naturally mirrors all influences on the method of determination, such as sample inhomogeneity, contamination and element loss, and the variations caused by the analytical process itself.

\section{Sample inhomogeneity}

Approximately half of the fat-free, dry sample consists of collagen- $\mathrm{N}$ and mucopolysaccharide ( $43 \%$ by weight), the remaining $57 \%$ being the mineral material (22).

Variations in the contents could be explained if the ratio of the organic to the inorganic part fluctuated, since some of the elements are contained almost exclusively in the mineral part (column 13 in tab. 4).

The mineral part of the investigated samples is, however, very constant. The scatter of the calcium contents can be considered as representative for the scatter of the mineral part; this is only $4.4 \%$. The mean $\mathrm{Ca} / \mathrm{P}$ ratio measured is $2.17(\sigma=0.17, \mathrm{n}=10)$ and thus corresponds approximately to that of hydroxyapatite $(\mathrm{Ca} / \mathrm{P}=2.15)$, whereas calcium phosphate has a $\mathrm{Ca} / \mathrm{P}$ ratio of 1.94 .

If one assumes hydroxyapatite to be the composition of the mineral phase, the investigated bones contained on average $54 \%$ mineral material. It is interesting to note that, with the exception of fluorine, those elements contained to the extent of almost $100 \%$ in the mineral $(\mathrm{Ca}, \mathrm{Na}, \mathrm{Sr}, \mathrm{Zn}$ ), do not show such a wide range of intraindividual distribution, compared with those which are also contained in larger proportions in the organic phase (Co, $\mathrm{Fe}, \mathrm{Sc}, \mathrm{Se}$ ). With the exception of iron, these are also, however, the elements with the lowest contents. The special role of iron will be discussed later. Surprisingly, the distribution of fluorine is rather inhomogeneous (mean standard deviation of the $\mathrm{F} / \mathrm{C}$ a ratio from .20 persons $\overline{\mathrm{Isd}_{1}}=25 \%$ ).

\section{External contamination}

An important source of contamination, especially with solid samples, is the tools which are used in sampling. Of those elements investigated here the hollow milling cutter, the extraction forceps and the blade of the diamond saw only contain the element iron in larger amounts (hollow milling cutter and forceps, tab. 2). The possibility of contamination with this element cannot, therefore, be excluded. The chromium in the tools, which represents $17-18 \%$ ( $\mathrm{Fe} / \mathrm{Cr}$ ratio 5:1), was not found, however, in any of the samples (detection limit ' for chromium about $1 \mathrm{mg} / \mathrm{kg}$ ). Contamination with iron is, therefore, smaller than $5 \mathrm{mg} / \mathrm{kg}$ with a mean iron content of $183 \mathrm{mg} / \mathrm{kg}$.

\section{Internal contamination}

Here the main sources of contamination are blood and bone marrow.

In figure 1 it can be seen that 4 of the elements investigated are present in total blood in a higher concentration than in bone. The content ratio is 11 for iron, 5 for selenium, 2.6 for sodium and greater than 225 for rubidium.

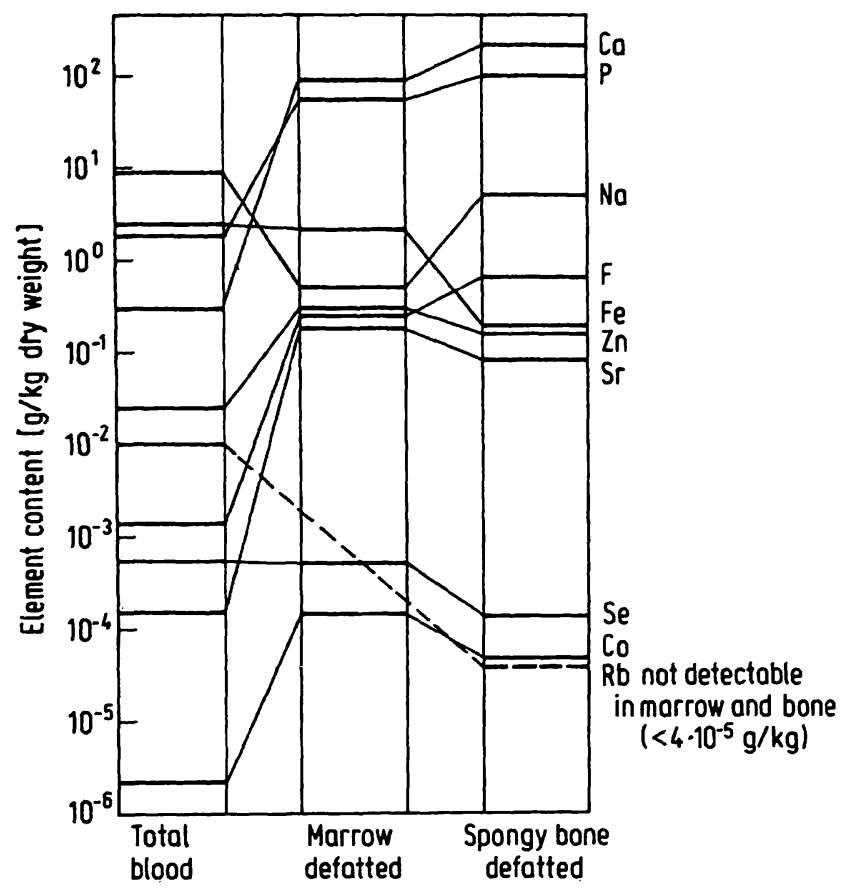

Fig. 1. Comparison of element contents of total blood, marrow and spongy bone. (Values for marrow and spongy bone from the present work: values for total blood from l.c. (8)).

No information is available in the literature on the residual blood content of the bone. In 1.c. (7) the blood : content of bone in the living organism is given at about $0.05 \mathrm{ml}$ of blood per gramm of bone mass. If the losses due to drying are taken into account this leaves a mass ratio of about $1 \%$ of blood in the bone. We suggest, that rubidium is a suitable "scout" element for the determination of the proportion of blood in the bone because of the large content ratio. The limit of detection for rubidium in bone using our method is $40 \mu \mathrm{g} / \mathrm{kg}$. As the rubidium content in the dry total blood is about $9 \mathrm{mg} / \mathrm{kg}$, the mass ratio blood/bone is less than about $0.4 \%$. With a mean bone iron content of $183 \mathrm{mg} / \mathrm{kg}$ this would represent a contamination by iron in the blood corresponding to less than $8.7 \mathrm{mg} / \mathrm{kg}$. 
All the trace elements found in the fat-free, dry bone marrow ( $\mathrm{Al}, \mathrm{Rb}$ and $\mathrm{Sc}$ were not detected in marrow) were present in larger contents than in the bone (fig. 1). The content ratios are: 11.3 for iron, 1.8 for zinc, 3.8 for selenium, 3.0 for cobalt and 2.3 for strontium. This shows the great importance of the blood marrow as a source of contamination in the analysis of trace elements in bone. As rubidium was not found in the marrow (detection limit $4 \mathrm{mg} / \mathrm{kg}$ ) it cannot, as with blood, be used as an indicator. It is not possible therefore despite the careful removal of the marrow, to ignore the fact that at least the value given for the iron content in bone might be too high.

\section{In ter-in dividual distribution}

A comparison of the arithmetic mean value (tab. 4, column 3) and the median (column 7) shows a symmetrical distribution with a small standard deviation for the three matrix elements $\mathrm{Ca}, \mathrm{P}$ and $\mathrm{Na}$. For the element fluorine the well-known unsymmetrical distribution tending towards higher contents was found (arithmetic mean value $626 \mathrm{mg} / \mathrm{kg}$, median $452 \mathrm{mg} / \mathrm{kg}$ ). Of all the elements investigated fluorine has the widest range of values. The distribution for the contents of the elements $\mathrm{Al}, \mathrm{Fe}, \mathrm{Se}, \mathrm{Sc}, \mathrm{Sr}$ and $\mathrm{Zn}$ is also more or less symmetrical, whereas the irregular distribution of the cobalt contents, on the other hand, is associated with a wide range of values and indicates a hitherto unknown source of contamination.

\section{Comparison with element determination using in-vivo activation analysis}

Mainly because of the unknown ratio of trabecular to compact bone a bone biopsy is only to a limited degree representative of the whole skeleton as far as the element content is concerned, even when the choice of the sampling spot is reproducible. Moreover the patient suffers such discomfort as a result of the method of sampling that a biopsy which is taken solely in the interest of determining the element content is certainly not a justifiable diagnostic measure when one considers the present state of the knowledge of trace element metabolism.

On the other hand a number of elements can be determined with the help of total or part body in-vivo neutron activation analysis, the radiation dose which the patient receives being about 1 rem.

A list of applications of this method can be found in 1.c. $(18,19)$. Could in-vivo neutron activation analysis be used to measure the total amount of matrix or trace elements in the skeleton? As far as trace elements are concerned the detection limit of the total body in-vivo method is much too high if the radiation dose is kept at an acceptable level.

The following matrix-elements were determined by total body measurements:
Oxygen, hydrogen, nitrogen, calcium, phosphorus, sodium, potassium and magnesium.

The in-vivo methods do not, however, discriminate between the element content of bone (which is of interest to us here) and that in other tissue and blood.

Whereas with an error of only a few percent the calcium mass of the whole body can be equated with that in the bone, this does not apply to phosphorus, and it is not in the least valid for the other elements.

With a biopsy the reference mass - the fat-free, dry bone - can be clearly defined, so that it is possible to obtain information on the element content but not on the mass of the element in the total bone. The in vivo analysis provides the total amount of the calcium in the bone; but it does not reveal the average calcium con tent of the bone, because the reference mass cannot be determined. In a number of diseases (osteomalacy, renal osteopathy) it is precisely the calcium and phosphorus contents which change.

To date no comparison has been made of the operative risk involved in biopsy sampling with radiation damage after a whole body dose of 1 rem.

\section{Bone Marrow}

No measurements of trace element contents in bone marrow have so far been published. The investigation of trace elements in the marrow would appear to be worthwhile, in order to determine the role of trace elements in the important double function of the marrow as haemotopoietic tissue and as the site of osteogenesis.

Marrow itself is a very complex matrix: The proportion of red and yellow marrow is dependent on age and varies from bone to bone. In the iliac crest the proportion of red marrow is about $40 \%$ in persons between the age of 40 and 70 years. Whereas about $80-85 \%$ of the yellow marrow consists of fat and $15 \%$ of water, the red marrow contains in addition to $4 \%$ water, and $40 \%$ fat about $20 \%$ protein (7), as well as erythrocytes, mainly granulocytes and also lymphocytes and other haemic cells.

The contents we measured are related to fat-free, dry marrow and are the mean values of 3 persons (tab. 5). Iron and selenium which have an important function in the haemic cells, are present in the marrow in the same concentration as in the total blood.

$\mathrm{Co}$ and Sr are enriched to a very high degree compâred with their contents in blood and bone (fig. 1), the content ratio marrow/total blood being 70 for cobalt and 1200 for strontium. These findings could lead to a practical application in the estimation of the radiation burden of marrow through ${ }^{60} \mathrm{Co}$ and ${ }^{90} \mathrm{Sr}$.

The matrix elements of the bone, $\mathrm{Ca}, \mathrm{P}$ and also fluorine are in fact present in smaller amounts than in the bone but are extremely enriched compared with the contents in the plasma: (content ratio màrrow/plasma in brackets) $\mathrm{Ca}$ (87), $\mathrm{P}(45), \mathrm{F}(200)$. 


\section{References}

1. Brätter, P., Gawlik, D., Lausch, J. \& Rösick, U. (1977) J. Radioanal. Chem. 37, 393-403.

2. Behne, D., Brätter, P., Keller, C. \& Rösick, U. (1974) Radioaktive Isotope in Klinik und Forschung, Bd. 11, 475-480, Urban und Schwarzenberg, München-Berlin.

3. Behne, D. (1981) J. Clin. Chem. Clin. Biochem. 19, 115120.

4. Burkhardt, R. (1956) Blut 2, 267-275.

5. Burkhardt, R. (1966) Klin. Wochenschr. 44, 326-335.

6. Burkhardt, R. (1966) Blut 14, 30-36.

7. Report of the Task Group on Reference Man (1975) ICRP Publication 23, Pergamon Press, Oxford.

8. Iyengar, G. V., Kollmer, W. E. \& Bowen, H. J. M. (1978) The Elemental Composition of Human Tissues and Body Fluids, Verlag Chemie, Weinheim, New York.

9. Batra, G. A. \& Bewley, D. K. (1973) J. Radioanal. Chem. 16, 275-280.

10. Buenafama, H. D. \& Rudelli, M. D. (1973) J. Radioanal. Chem. 16, 269-273.

11. Goode, G. C. (1972) Anal. Clin. Acta 58, 363.

12. Liebscher, K. \& Smith, H. (1968) Arch. Environ. Health 17, 881-890.

13. McKown, D., Kay, M., Gray, D., Abu-Samra, A., Eichor, M. \& Vogt, J. (1971) in: Nuclear Methods in Environmental Research (Vogt, J. R., Parkinson, T. F. \& Carter, R. L. eds.), University of Missouri, Columbia Mo, pp. 150-157.
14. Söremark, R. \& Bergmann, B. (1969) Isotopica 2, 5-19.

15. Sowden, I. M. \& Stitch, S. R. (1957) Biochem. J. 67, 104 109.

16. van der Mark, W. \& Das, H. A. (1972) J. Radioanal. Chem. $13,107-124$.

17. Yamagata, N. (1962) J. Radioat. Research 3, 9-30.

18. Cohn, S. H., Cinque, T. J., Dombrowski, C. S. \& Letteri, J. M. (1972) J. Lab. Clin. Med. 79, 978-994.

19. Cohn, S. H. (1978) in Textbook of Nuclear Medicine: Basic Science (Rocha, A. F. G. \& Harbert J. C. eds.), Lea \& Febiger, Philadelphia pp. 394-406.

20. Behne, D., Brätter, P., Gawlik, D., Keller, C., Möller, J. \& Rösick, U. (1977) in: Medizinische Physik Bd. 2 (Lorenz, W. J. ed.), Hüthig Verlag, Heidelberg, pp. 239-252.

21. Gatschke, W. \& Gawlik, D. (1980) J. Clin. Chem. Clin. Biochem. 18, 403-406.

22. Documenta Geigy, Wissenschaftliche Tabellen (1975) Georg Thieme Verlag, Stuttgart.

23. Intercomparison of Minor and Trace Elements in IAEA Animal Bone (H-5). Progress Report No. 1, 1982.

Dr. D. Gawlik

Bereich Kernchemie und Reaktor

Hahn-Meitner-Institut

Glienicker Str. 100

D-1000 Berlin 39 


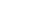

